Apidologie, 1987, 18 (1), 1-10

\title{
A SERIOLOGICAL APPROACH TO THE DETECTION OF ACARAPIS WOODI PARASITISM IN HONEY BEES USING AN ENZYME-LINKED IMMUNOSORBENT ASSAY
}

\author{
David RAGSDALE and Basil FURGALA \\ Department of Entomology, University of Minnesota \\ Saint-Paul, Minnesota, 55108, USA
}

\begin{abstract}
SUMMARY
Denaturing polyacrylamide gel electrophoresis (PAGE) in the presence of sodium dodecyl sulfate (SDS) was performed using a 7-30\% gradient slab gel to determine if unique polypeptides could be identified in extracts of $A$. woodi infested tracheae. Antisera were also raised against extracts of $A$. woodi infested tracheac and used as the primary antibody in a direct enzyme-linked immunosorbent assay (ELISA).

These studies reveal at least 3 unique polypeptides in the $A$. woodi extracts with molccular weights estimated at $51,500,28,400$ and 18,000 daltons. Based on the electrophoretic work there is a great deal of homology between normal honey bec proteins and extracts of $A$. woodi infested tracheac. The ELISA using unabsorbed primary antibody could detect as little as $4.4 \mathrm{ng}$ protein/ml (less than 1 mite equivalent) of the $A$. woodi extract. The ELISA was also able to detect the presence of $A$. woodi protein in samples of 400 noninfested honcy bee tracheac to which, either $1,2,3$ or $4 \mathrm{~A}$. woodi infested tracheac were added. Cross reactivity of normal honcy bee proteins found in both hemolymph and an extract of thoracic muscle and associated fat body in the ELISA prevented detection of $A$. woodi proteins in extracts of prothoracic discs. If specificity could be improved, the ELISA has sufficient sensitivity to detect $A$. woodi proteins in extracts of prothoracic discs. Cross absorption of primary antisera did improve specificity but did not climinate cross reactivity and was accompanied by an unacceptable loss in sensitivity.
\end{abstract}

\section{INTRODUCTION}

The honey bee tracheal mite, Acarapis woodi, is a recent introduction to North America (Wilson and Nunamaker, 1982). As of Sept. 30, 1982, the mite had not been detected in the United States (Shimanuki et al., 1983) ; but, in 1984 mite infestations were discovered, first in Texas (Fore, 1984) and then Florida (Anonymous, 1985). Relatively little is known about the epidemiology and pathology of tracheal-mite infestations. There are conflicting reports on 
whether colonies parasitized with $A$. woodi produce less honey (WILSON and Nunamaker, 1982 ; Bailey, 1985) and whether the stress of $A$. woodi parasitism increases winter mortality (Anonymous, 1968 in Wilson and Nunamaker, 1982 ; BaILeY, 1985). Diagnosis of the presence of $A$. woodi is a time consuming and tedious task involving careful dissection, clearing of tissue in $\mathrm{KOH}$, followed by microscopic examination (ConNER, 1984). Rapid diagnosis is essential for certification of colonies and apiaries as mite-free. Additionally, many states and provinces are now requiring certification before allowing importation of honey bees from known mite infested areas. A method to accurately and quickly process a sample of honey bees is needed.

Serodiagnosis is commonly used in agriculture to support seed certification programs to assure that either true seed or vegetative seed is free from plant pathogens. For example, potatoes are routinely screened for the presence of several viruses using an enzyme-linked immunosorbent assay (ELISA) (Gugerli, 1983). Also an ELISA has recently been developed to detect a microsporidian infection in mosquitos (GreEnstone, 1983). And an ELISA has been used in Australia for diagnosing European foulbrood in honey bees (Pinnock and Featherstone, 1984).

A serological test for detecting $A$. woodi would be useful since ELISAs have proven to be rapid and extremely sensitive. However, the most difficult problem to overcome in any serological test is specificity, i.e., the assay must not cross react with normal host (honey bee) proteins. The objective of this study was to evaluate the feasibility of detecting $A$. woodi parasitism with an ELISA.

\section{MATERIAL AND METHODS}

\section{Sample preparation}

Samples of prothoracic tracheal trunks, thoracic muscle tissue with associated fat body (but without tracheal trunks) and hemolymph were collected from honey bees infested with $A$. woodi and from a colony of known mite-frec "Starline " honey bees maintained at the University of Minnesota. Worker honey bees infested with $A$. woodi were initially obtained from Mexico and later from infested colonies found in Minnesota. Live mite-infested honey bees from Minncsota were maintained in the laboratory for several days. Prothoracic tracheal trunks werc dissected and mite-infested tracheac were placed in $0.5 \mathrm{ml}$

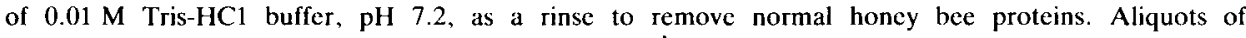
approximately 100 tracheac were held at $-20^{\circ} \mathrm{C}$. Tracheal trunks from mite-free honey bees were prepared and stored as above. Hemolymph was collected from both live mite-free and mite-infested honey bees by carefully piercing the intersegmental membrane on the abdomen with a needle and collecting the droplet in a $2 u$ pipet. Hemolymph was immediately diluted 2 -fold with cold Tris-HC1 buffer containing $0.01 \%$ phenylthiourea to prevent melanization. Extracts of muscle tissue with its associated fat body and mite-infested and mite-free tracheae were triturated in a Potter-Elvehjem tissue grinder with Tris- $\mathrm{HCl}$ buffer, centrifuged and the supernatant collected. Aliquots of $50 u$ were kept frozen at $-20^{\circ} \mathrm{C}$ until needed. Protein analysis was performed on these samples using the Bio-Rad micro assay with ovalbumin as a standard. An estimate of the average amount of protein in mite-infested and mite-free tracheae was determined. 


\section{Polyacrylamide gel electrophoresis}

Denaturing polyacrylamide gel electrophoresis (PAGE) in the presence of sodium dodecyl sulfate (SDS) was performed following the methods of LAEMmLI (1970). Gradient slab gels from 7-30\% polyacrylamide, $0.75 \mathrm{~mm}$ thick were cast. Proteins were dissociated in the presence of $1 \%$ SDS and $5 \%$ 2-mercaptoethanol by heating the samples in a $100^{\circ} \mathrm{C}$ water bath for 3 minutes. Ten ug of protein were used in a single slab gel track. Marker proteins used were the high and low molecular weight standard kits MW-SDS-70L and MW-SDS-200 (Sigma Chemical Co, Saint-Louis, Missouri, USA). The subunit molecular weights of these standards ranged from 205,000 to 14,200 daltons. The electrophorectic conditions were to prerun the gel for $1 \mathrm{~h}$ at 70 volts, add the samples and, after ten minutes at 300 volts, maintain a constant 150 volts for $10 \mathrm{~h}$. Silver staining was performed according to MERRIL et al. (1981). Relative mobility of the protein standards was plotted versus $\log$ of their molecular weight. The standard curve was used to estimate molecular weights of the major polypeptide bands in each sample. The electrophoretic characterization of the $A$. woodi extracts is necessary in order to identify and confirm the presence of mite-specific proteins in these extracts.

\section{Serological procedures}

Mice were immunized with the electrophoretically characterized extract of $A$. woodi parasitized tracheae. The first injection was emulsified 1:1 with Freund's complete adjuvant and 20 ug were given intrasmuscularly (im). Mice were boosted im after 8 weeks with 25 ug emulsified in incomplete Freund's adjuvant. Animals were test bled 2 to 4 weeks after the last injection. Antiscra were diluted 1:10 with PBS, containing $10 \%$ bovine serum albumin (BSA) as a cryoprotectant, and stored at $-20^{\circ} \mathrm{C}$ until needed.

An indirect ELISA was developed using the horseradish peroxidase/o-phenylenediamine system in microtiter plates following the method of VolLER et al. (1976). The second antibody was goat anti-mouse IgG conjugated with horseradish peroxidase (IgG-HRPO) (Sigma Chemical Co.). To determine optimum reagent concentrations, checkerboard titrations were set up using all combinations of $10,7.5,5.0,2.5$ and $1.0 \mathrm{ug} / \mathrm{ml} A$. woodi antigen, a 1:100,1:200,1:400, 1:1000 and 1:1500 dilution of the anti-A. woodi antisera and 1:1000 dilution of the second antibody. All assays were performed in 96-well microtiter plates (Dynatech, Immulon II) using $100 u$ l volumes.

Sensitivity and specificity of the ELISA were determined by coating the polystyrene microtiter plates with 2-fold dilutions of the $A$. woodi extract, honey bee thoracic muscle and associated fat body extract

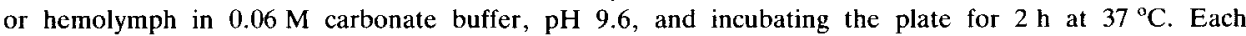
dilution was replicated 4 to 6 times. Control wells contained buffer only during coating and normal mouse serum in place of antisera against $A$. woodi. Absorption of each well was read with a Dynatech MR 590 spectrophotometer at $490 \mathrm{~nm}$. Linear regression was performed for each antigen titration. Sensitivity of each ELISA was determinated by taking the $95 \%$ upper confidence interval of the $\mathrm{Y}$ intercept and solving for $\mathrm{X}$ in the regression equation.

Field testing of the ELISA was performed in 2 ways. First, to 400 noninfested honey bee tracheae either $0,1,2,3$ or $4 \mathrm{~A}$. woodi infested tracheae were added. The tracheae were triturated in 250 ul of carbonate (coating) buffer, centrifuged and duplicate $100 \mathrm{ul}$ samples of supernatant were used as the coating antigen and incubated as above. Second, 20 prothoracic dises (10 known to be mite-infested and 10 without mites) were individually triturated in $250 \mathrm{ul}$ of coating buffer. Following centrifugation the supernatant was used as the coating antigen and 42 -fold dilutions of $100 \mathrm{ul}$ each were used. The prothoracic discs represent what would be used in a field test.

Cross absorption of $100 \mathrm{ul}$ of antisera raised against $A$. woodi infested tracheae was accomplished by adding $2 \mathrm{mg}$ of both the extract of thoracic muscle with associated fat body and hemolymph from mitefree honey bees. The mixture was incubated for $2 \mathrm{~h}$ at $37^{\circ} \mathrm{C}$ followed by overnight at $4{ }^{\circ} \mathrm{C}$. The cross absorbed antisera was centrifuged at $12000 \mathrm{xg}$ for $10 \mathrm{~min}$, the supernatant diluted to $1: 1000$ with TT buffer containing $1 \% \mathrm{BSA}$ and evaluated in the ELISA for specificity and sensitivity as described above. 


\section{RESULTS}

Protein determinations of the extracts of infested tracheae averaged $497.9 \pm 145.5 \mathrm{ng}$ protein per trachea while extracts of mite-free trachea averaged only $39.4 \pm 14.5 \mathrm{ng}$ protein per trachea. The number of mites in all stages and eggs combined per infested trachea averaged 34.6 (range 31-39); thus, a single life stage would contain on average $14.4 \mathrm{ng}$ protein. The percent parasitism of the honey bees collected in Minnesota was nearly $40 \%$, while the honey bees from Mexico were parasitized only about $20 \%$ of the time.

The PAGE-SDS (Fig. 1) shows at least 3 polypeptides which are unique to extracts of mite-infested tracheae. Many bands in the $A$. woodi extract had relative mobilities similar to bands in hemolymph and thoracic muscle extracts and may be identical proteins. The 3 polypeptides unique to the $A$. woodi extract had molecular weights estimated at 51,500, 28,400 and 18,000 daltons.

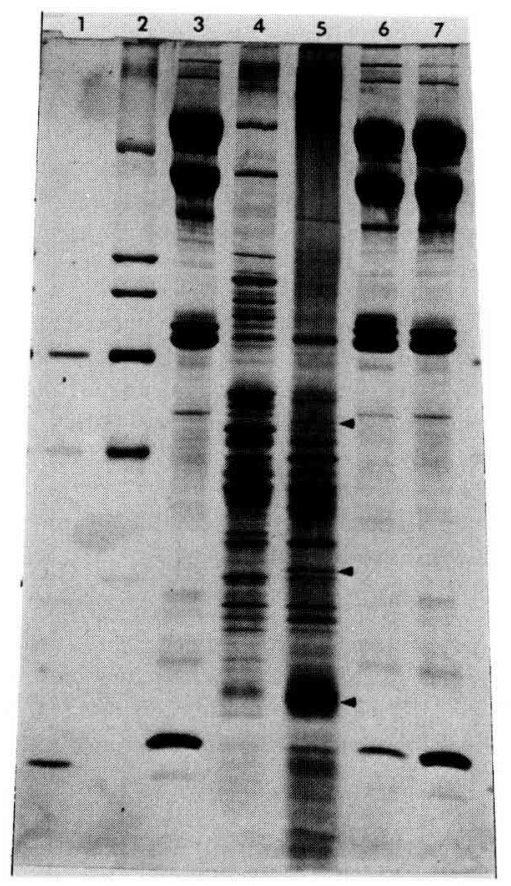

FIG. 1. - Gradient (7-30\%) polyacrylamide gel electrophoresis in the presence of sodium dodecyl sulfate.

Tracks 1 and 2 are molecular weight standards, tracks 3 and 7 are hemolymph samples from a mite-free colony of "Starline » honey bees, track 4 is extract of thoracic muscle and associated fat body of miteinfested honey bees collected in Minnesota, track 5 is and extract of $A$. woodi infested tracheae, and track 6 is hemolymph from mite-infested honey bees collected in Minnesota. 
Only a few PAGE-SDS gels included an extract of mite-free trachea because of the small amount of protein associated with the mite-free trachea. These 3 polypeptides unique to $A$. woodi infested trachea were not found in extracts of mite-free trachea.

Optimum concentrations of reactants in the ELISA were determined as the minimal amount of antigen and primary antibody (anti- $A$. woodi) which gave an absorption of 1.00 or greater after $30 \mathrm{~min}$. of substrate incubation. A 1:1 500 dilution of mouse anti- $A$. woodi antisera gave an average absorption of 1.107 when plates were coated with $1.0 \mathrm{ug} / \mathrm{ml}$ of $A$. woodi extract and the second antibody (goat anti-mouse IgG-HRPO) was used at a 1:1000 dilution $(1 \mu \mathrm{g} / \mathrm{ml})$. Data from the titration of $A$. woodi extract, extracts of thoracic muscle with associated fat body, and hemolymph with antisera raised against A. woodi are shown in figs. 2 and 3 , respectively. The equation $\mathrm{y}=0.072+0.0075 \mathrm{x}$ explains $97.2 \%$ of the variation in fig. 2 . The equations $y=0.020+0.000069 x$ and $y=0.049+0.000127 x$ explain 97.0 and $94.4 \%$ of the variation in the titration of the extract of thoracic muscle with associataed fat body, and hemolymph, respectively (Fig. 3). The least amount of protein detected in ELISA for the extracts of $A$. woodi infested tracheae, thoracic muscle with associated fat body, and hemolymph was 4.4, 266 and $363 \mathrm{ng} / \mathrm{ml}$, respectively. Thus the ELISA is capable of detecting a single mite.

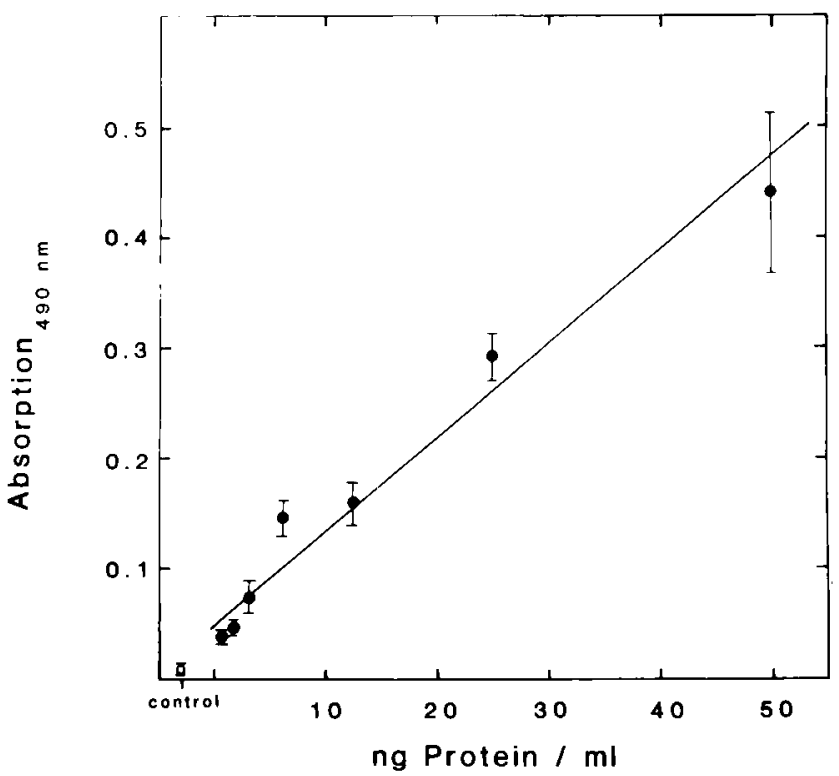

FIG. 2. - The relationship between protein from extracts of A. woodi infested tracheae and absorption at $490 \mathrm{~nm}$ in the indirect ELISA.

Data points are means with $95 \%$ confidence intervals for 6 observations at each protein concentration ; the line was fitted using least square linear regression. 


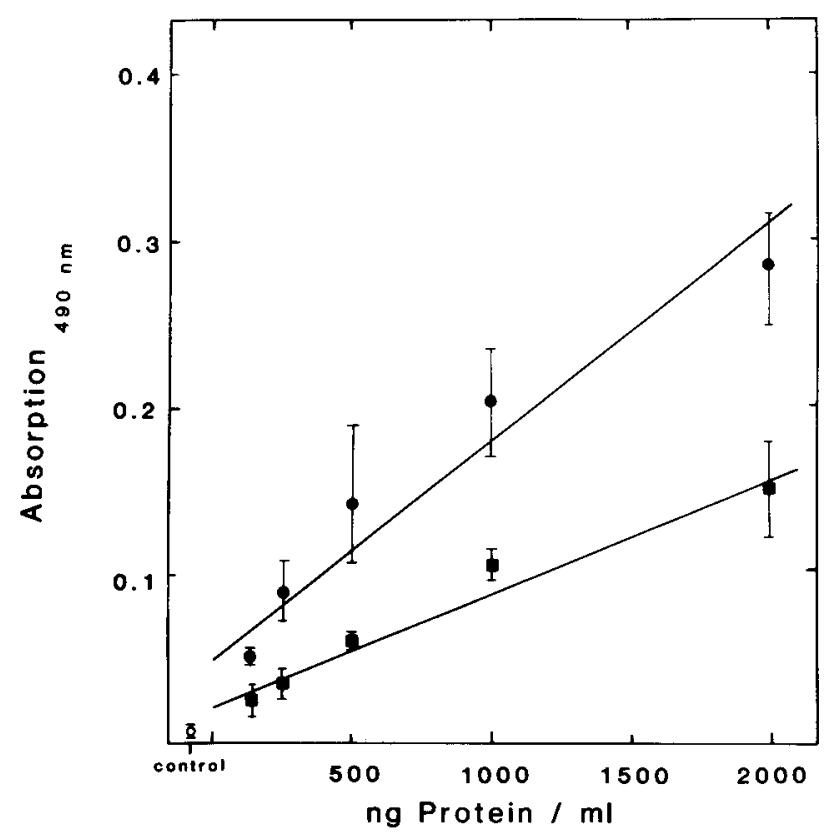

Fig. 3. - The relationship between protein from extracts of thoracic muscle and associated fat body from mite-free honey bees ( $-\mathbf{\square})$ and hemolymph collected from mite-free honey bees and absorption at $490 \mathrm{~nm}$ in the indirect ELISA.

Data points are the means with $95 \%$ confidence intervals for 4 observations at each protein concentration; the lines were fitted using least square linear regression.

The ELISA was capable of detecting the presence of a single mite-infested trachea when mixed with 400 uninfested tracheae (Tabl. 1). However, there was a high background absorbence in control wells containing an extract of 400 uninfested tracheae due to the presence of cross reacting normal bee proteins.

TABL. 1. - Mean absorption values in the ELISA detecting 0 to $4 \mathrm{~A}$. woodi infested tracheae in a pool of 400 uninfested tracheae

\begin{tabular}{c|c|c}
\hline $\begin{array}{c}\text { Number of mite } \\
\text { infested tracheae }\end{array}$ & $\begin{array}{c}\text { Mean absorption at } \\
490 \mathrm{~nm} \text { in the ELISA }\end{array}$ & $\begin{array}{c}\text { Protein concentration } \\
\text { ug/ml }\end{array}$ \\
\hline 0 & $0.408 \mathrm{a}^{*}$ & 262 \\
1 & $0.520 \mathrm{~b}$ & 32 \\
2 & $0.760 \mathrm{c}$ & 71 \\
3 & $0.760 \mathrm{c}$ & 54 \\
4 & $0.718 \mathrm{c}$ & 64 \\
\hline
\end{tabular}

* Numbers followed by the same letter are not significantly different using Duncan's's new multiple range $(P=0.05)$. 
When an entire prothoracic disc was triturated and used as the antigen, the ELISA could not distinguish between an mite-infested or non-infested tracheae because of the extent of this cross reaction.

Cross absorbing the primary antisera changed the sensitivity of the ELISA so that the least amount of protein detected in the ELISA was 109, 19,574 and $46,398 \mathrm{ng} / \mathrm{ml}$ of extracts of $A$. woodi infested tracheae, extracts of thoracic muscle with associated fat body, and hemolymph, respectively. Specificity was increased by a factor of 2.9 for thoracic muscle and fat body ([19,574/109]/ [266/4.4]) and by a factor of 5.2 for hemolymph $([46,398 / 109] /[363 / 4.4])$ but there was nearly a 25 fold loss in sensitivity for detecting $A$. woodi extracts.

\section{DISCUSSION}

PAGE-SDS demonstrated there were indeed unique proteins present in extracts of $A$. woodi infested tracheae. The majority of the polypeptides in this extract had relative mobilities identical to either hemolymph, extracts of thoracic muscle with associated fat body or extracts of uninfested tracheae from nonparasitized honey bees (the latter is not shown in fig. 1). Over $90 \%$ of the protein in a mite-infested trachea was due to the presence of $A$. woodi; however, some of this protein may be normal honey bee proteins entering the tracheae through mite feeding sites. Also it has been shown that the external parasitic mite, Varroa jacobsoni, which feeds on hemolymph, has a unique ability to resorb ingested hemolymph into its own hemolymph and eggs (Tewarson and Engels, 1982; Tewarson and JANY, 1982). Because only 3 unique proteins were found in extracts of $A$. woodi infested tracheae $A$. woodi may also incorporate normal host proteins into its body without structural (antigenic) changes. However, the major hemolymph bands were consistently absent or present only at low levels in the extracts of mite-infested trachea (Fig. 1). Nevertheless, since unique proteins have been consistently found in these extracts, it was possible to produce antisera against them.

The ELISA was sensitive enough to detect a single mite-infested trachea mixed with a pool of 400 nonparasitized tracheae. However, the protein concentration of the supernatant from triturating prothoracic discs averaged $25.8 \mathrm{mg} / \mathrm{ml}$, and proteins found in extracts of thoracic muscle and associated fat body cross react with the antisera when present at concentrations $>266 \mathrm{ng} /$ $\mathrm{ml}$ for unabsorbed antisera or $19,574 \mathrm{ng} / \mathrm{ml}$ after cross absorption. Thus assaying these extracts for the presence of mite proteins with the polyclonal antisera was not possible. Dilution of prothoracic disc extracts so that protein concentration would be lower than the detection endpoint for thoracic muscle would dilute the $A$. woodi proteins far below its lowest detectable level ( $4.4 \mathrm{ng} / \mathrm{ml}$ prior to cross absorption or $109 \mathrm{ng} / \mathrm{ml}$ after cross absorption). 
Improvement of the specificity of the ELISA is necessary before the assay would be useful. Specificity was not enhanced sufficiently by cross absorbing antisera with extracts of thoracic muscle with associated fat body and hemolymph. Cross absorption left antisera with poor avidity. Another way specificity could be improved is to use monoclonal rather than polyclonal antisera in the ELISA. Monoclonal antibodies have the resolving power of the vertebrate immune system and specificity would be absolute, i.e., only $A$. woodi proteins would be detected. The ELISA assays developed and reported here could serve as a 3-part screening system for the production of monoclonal antibodies. Once complete specificity is obtained, the ELISA has been shown to be sensitive enough to detect the presence of $A$. woodi in an extract of a single infested trachea.

Received for publication in April 1986. Accepted for publication in August 1986.

\title{
ACKNOWLEDGEMENTS
}

We thank Mr. Steven Duff and Ms. Sally Michal for technical help. Thanks are also due Drs. H. Shimanuki (USDA/ARS, Beltsville, Maryland, USA), F. A. Eischen (Department of Entomology, University of Georgia, Athens, Georgia, USA), and Mr. Phil Lima (USDA/APHIS, Hyatteville, Maryland, USA) for arranging the shipment of infested Mexican honey bees. This article is paper number 14,910 of the Minnesotaa Agric. Exp. Stn.

\author{
RÉSUMÉ \\ ÉTUDE SÉROLOGIQUE DE LA DÉTECTION DU PARASITISME DE L'ABEILLE \\ PAR ACARAPIS WOODI À L'AIDE DE LA TECHNIQUE ELISA
}

Une électrophorèse sur gel de polyacrylamide dénaturant (PAGE), en présence de sulfate dodécyle de sodium (SDS) a été effectuée en utilisant un gel en plaque (gradient de 7 à $30 \%$ ), pour essayer d'identifier des polypeptides spécifiques dans les extraits de trachées parasitées par $A$. woodi. De plus ces immunsérums ont été testés avec des extraits de trachées parasitées et utilisćs comme anticorps primaires dans un test immunocnzymatique (ELISA).

Ces recherches ont montré la présence de 3 polypeptides spécifiques de poids moléculaire 51500 , 28400 et 18000 daltons. Les recherches par électrophorèse montrent qu'il existe une très grande homologie entre les protéines normales de l'abeille et les extraits des trachées parasitées par $A$. woodi. La plus petite quantité de protéines détectée en ELISA en utilisant des immunsérums primaires non absorbés est de 4,4 ng de protéines/ml (moins d'un équivalent acarien). Le test a pu détecter la présence d'une seule trachée parasitée parmi 400 autres trachées non parasitées (Tabl. 1). Des absorptions croisées des immunsérums primaires avec les extraits de muscles thoraciques et de corps gras associé d'une part et avec l'hémolymphe d'autre part modifient la sçnsibilité du test ELISA: la plus petite quantité de protéine détectée est de $109 \mathrm{ng} / \mathrm{ml}$ dans les extraits de trachées parasitées, de 19574 dans les extraits de muscles thoraciques et de corps gras associé et de 46398 dans l'hémolymphe. Si l'on pouvait améliorer la spécificité, le test ELISA serait suffisamment sensible pour identifier les protéines d'A. woodi dans les extraits de disques prothoraciques. Les absorptions croisées des immunsérums primaires améliorent bien la spécificité mais n'éliminent pas la réactivité croisée et s’accompagnent donc d'une perte de sensibilité non acceptable. 


\section{ZUSAMMENFASSUNG}

\section{SEROLOGISCHE VERSUCHE ZUR AUFKLÄRUNG DES ACARAPIS WOODI PARASITISMUS BEI DER HONIGBIENE MIT HILFE EINES ELISA-TESTS}

Eine denaturierende Polyacrylamid-Gel-Elcktrophorese (PAGE) mit Natriumdodezylsulfat (SDS) wurde mit Hilfe einer Gelplatte (Gradient : 7-30\%) durchgeführt, um festzustellen, ob spezifische Polypeptide aus Extrakten von mit $A$. woodi infizierten Tracheen identifiziert werden können. Außerdem wurden Antisera gegen Extrakte von $A$. woodi-infizierten Tracheen gezüchtet und als Primär-Antikörper bei einem direkten enzymgebundenen Immunosorbent Assay (ELISA) verwendet.

Dicse Untersuchungen ergaben 3 spezifische Polypeptide mit Molekulargewichten von 51 500, 28400 und 18000 Dalton in den A. woodi-Extrakten. Aufgrund der elektrophoretischen Untersuchungen wurde klar, daß sehr viel Homologie zwischen den normalen Proteinen der Honigbiene und Extrakten der mit $A$. woodi infizierten Tracheen besteht. Der ELISA-Test konnte bei Verwendung von unabsorbierten Primärantikörpern nicht mehr als $4.4 \mathrm{ng}$ Protein/ml (weniger als 1 Milbenäquivalent) aus den $A$. woodiExtrakten isolieren. Der ELISA-Test war außerdem in der Lage A. woodi-Proteine in Stichproben aus 400 nichtinfizierten Tracheen der Honigbiene zu identifizieren, wenn 1, 2, 3 oder 4 infizierte Tracheen beigemengt wurden (Tabl. 1). Kreuzreaktivität von normalen Proteinen der Honigbiene zum einen in der Hämolymphe und zum anderen in Extrakten der Thoraxmuskulatur sowie des assoziierten Fettkörpers verhindern beim ELISA-Test die Identifizierung der A. woodi-Proteine in Extrakten von Prothoraxscheiben. Wenn die Spezifität verbessert werden könnte, so sollte der ELISA-Test genügend sensitiv sein, um A. woodi-Proteine in Extrakten von Prothoraxscheiben zu identifizieren. Kreuzabsorptionen von Primärantisera verbesscrn dic Spezifität aber eliminieren nicht dic Kreuzreaktivität und wurden daher von nicht akzeptablem Verlust an Sensitivität begleitet.

\section{REFERENCES}

Anonymous, 1968. - Acarinc. Advisory Leaflet, no 30, pp. 1-6, British Ministry of Agriculture, Fisheries and Foot. London. England.

Anonymous, 1985. - Honcybee tracheal mites Florida among infested statcs. Plant Industry News, 26 1-3.

Bailey L., 1985. - Acarapis woodi : a modern appraisal. Bee World, 66, 99-104.

Conner L., 1984. - Tracheal mite diagnosis. Speedy Bee, 13, 16.

FORE T., 1984. - Acarine mites found in Texas apiaries. Speedy Bee, 13, 1, 3.

Greenstone M.H., 1983. - An enzyme-linked immunosorbent assay for the Amblyospora sp. of Culex salinarius (Microspora: Amblyosporidac). J. Invertebr. Pathol., 41, 250-255.

Gugerli P., 1983. - Use of enzyme immunoassay in phytopathology. In Immunoenzymatic Techniques, S. Avrameas et al., eds., Elscvicr Science Publishers, pp. 369-384.

LaEmmLi U.K., 1970. - Cleavage of structural proteins during the assembly of the head of bacteriophage T. Nature. 227. 680-685.

Merril C.R., Goldman D., Sedman S.A., Ebert M.H., 1981. - Ultrasensitive stain for proteins in polyacrylamide gels shows regional variation in cerebrospinal fluid proteins. Science, 211, 1437-1438.

Pinnock D.E., Featherstone N.W., 1984. - Detection and quantification of Melissococcus pluton infection in honcybce colonics by means of enzyme-linked immunosorbent assay. J. Apic. Res., 23, $168-170$.

Shimanuki H., Knox D.A., Delfinado-Baker M., Lima P.J., 1983. - National honey bee mite survey (1). Apidologie, 14, 329-332.

Tewarson N.C., ENGels W., 1982. - Undigested uptake of non-host proteins by Varroa jacobsoni. J. Apic. Res., 21, 222-225.

TeWARSON N.C., JANY K.D., 1982. - Detcrmination of protcolytic activity in Varroa jacobsoni an ectoparasitic hemophagous mite of honey bees (Apis sp.). Apidologie, 13, 383-389.

Voller A., Bidwell D.E., Bartlett A., 1976. - Enzyme immunoassays in diagnostic medicine theory and practice. Bull. W. H. O., 53, 55-65.

WiLson W.T. Nunamaker R.A., 1982. - The infestation of honey becs in Mexico with Acarapis woodi. Am. Bee J., 122, 503-505, 508 . 